\title{
Walter Gropius: The Fagus Factory
}

\author{
Ju XUE \\ Department of Landscape Engineering \\ Guangdong Eco-Engineering Polytechnic (GDEEP) \\ Guangzhou, China \\ e-mail: zcxju@126.com
}

\begin{abstract}
This article mainly embarks from the angle of Walter Gropius' architectural thought, through the analysis of his classic works, discussing his thoughts on the impact of architectural design.
\end{abstract} glass

Keywords-walter gropius; modern architecture; bauhaus;

\section{INTRODUCTION}

Walter Gropius, a German architect and architectural educator, founder of the Bauhaus School, is widely regarded as one of the pioneering masters of modern architecture. His ideas had a broad impact among the architects in the world from the 1920s to the 1950s. He believed that the building design idea should move forward with the times and new ideas of the era should be created. He actively advocated the unity of design and craft, and the combination of art and technology, fusion of function, technology and economic benefits, and all of these determined the characteristic and direction of modern architecture style. His design has the distinctive characteristics of the democracy and socialism. The Bauhaus School he founded is recognized worldwidely as the birthplace of modern architecture.

\section{ARCHITECTURAL THOUGHT}

\section{A. Synonym with Modern Architectural Thought-Bauhaus}

Gropius founded the Bauhaus School, the world's first truly school, which was designed for the development of modern design education, opening a new era for the design education in the industrial age. Gropius put forward the new design idea unity of art and technology. In his view, a new design school must be formed to impact a country's industry. The Bauhaus School advocated design freedom and combination of handicraft and machinery production, disapproved of imitation and routinism scholasticism, stressed exchanges between the various arts, and called for learning from painting and sculpture. And also the school emphasized to train students' practical ability and theoretical quality to guarantee the coordination between school education and social production. Under the influence of Gropius, Some radical artists came to teach at the Bauhaus School, which enriched design ideas and techniques. Gradually, a new style of art and architecture was produced at the Bauhaus School. That was emphasis on practicability, the technical performance and aesthetic properties of new materials, simple shape and versatile composition. (Referring with Fig.1)

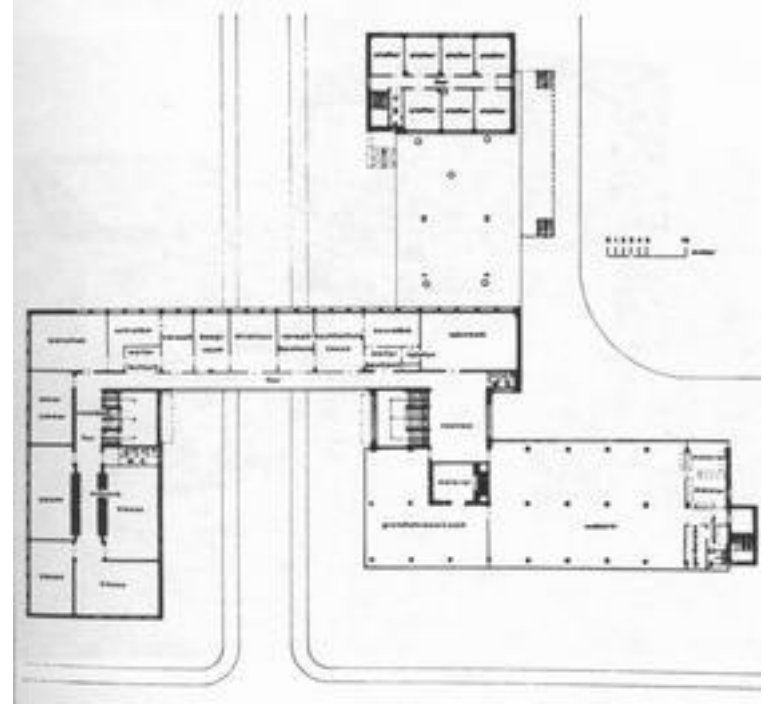

Figure 1. Example of a layout figure caption

Making full use of education, classroom teaching and factory practice, the Bauhaus School formed a new education system combining artistic education with handwork, which broke the shackles of classical architectural tradition. So the Bauhaus School became one of the most radical centers for art and architecture in Europe, which promoted the building reform movement.

\section{B. Modern Construction Methods}

Gropius' emphasis on scientific and technological progress is not only reflected in architectural design, but also in the building's construction.

Gropius believed that there must be a new design concept to influence Germany's construction sector. That time in Europe, building structure and modeling were complex and ornate. The style of angle towers, pillars, windows and vault, whether Gothic or Victorian, both emphasized the idea of artistic appeal which made the building full of religious mythology influencing on the secular life, and such building styles were unable to adapt to industrial mass production. Because of this, he presented his new design style which is art with science, design with practice. And most importantly, this kind of design can be mass-produced on an assembly line in a factory in a lower cost. 
In terms of modern construction, he was not only confined to the theory, but also studied in practice. At the Bauhaus School, he created a series of workshops, such as carpentry, masonry, steel and etc. He taught students how to make the practical standards meet the expression of designer's idea and how to bring the capabilities of a house or a piece of equipment into full play in a certain shape and contour.

In 1932, the Bauhaus school held its first exhibition which contained industrial products and office buildings. From the exhibition industrialists were aware of the advantage of making full use of the material itself and its decoration which can reduce the cost of products and give them more benefits.

In 1938, in view of energy saving, Gropius began to use new materials and technologies in the house he designed. With glass brick walls dividing the space, the light can also seep in and the South side of the cornice perfectly designed by Gropius can hide the summer sun and emit heat, which made the house can withstand the heat in summer and resist the lowest record temperature $-21^{\circ} \mathrm{C}$ in winter. In other houses, Gropius also tried to use lightweight materials and fabricated construction methods.

He combined theory with practice and embodied his Bauhaus ideas in practice: simplicity, functionality and the unity. Meanwhile, his attempt provided a powerful method and technical support for the development of modern architecture.

\section{THE FAGUS FACTORYS}

Designed by Walter Gropius and Adolf Meyer in 1911, the Fagus Factory fully embodied the combination of art and technique, and paid attention to the function, technique and economic effects of the architecture. It was the world's first building which fully used reinforced concrete structure and glass curtain walls, which had important academic value in architectural history.

Based on Gropius's architectural function idea, the Fagus Factory was laid out according to the purpose, nature and interrelation of the space,

The Fagus Factory adopted the symmetrical construction techniques, the brick used in the main facade while a lightweight material glass used in the side, which brought out a striking contrast. Transparent glass accentuated the staircase inside which made the whole building extraordinarily lightweight and neat. This was the first building using light-weight transparent material, which had epoch-making significance at that time. (Referring with Fig.2)

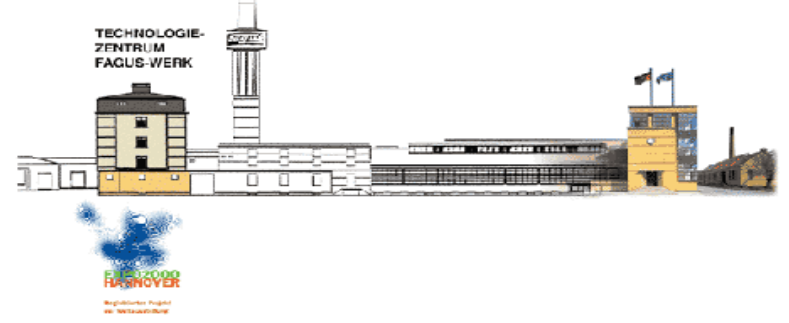

Figure 2. Example of an elevation figure caption
This three-story building was built by a reinforced concrete structure. Its walls were made of lightweight metal panels and glass which only existed as maintenance components and were completely detached from the loadbearing pillars. So the house appeared light and through the glass, you can clearly see indoor and outdoor and light fell into the room without hindrance. In the daytime, before the critical point of illumination, the office staff can get adequate lighting from the glass without the help of artificial lighting. In the corner of the building, the walls or corner post were replaced by glass which made the building no longer dull and heavy. Lightweight and transparent glass walls turned over naturally, smoothly and continuously, which formed a sharp contrast with the thick and stocky building's entrance. All of this made the thick walls disappear, and more space can be used. Before Gropius, no architects dared to do so. At that time most of the factories had no windows, while Gropius boldly introduced to use glass windows, bringing the dark, stained factories full of light. It is no doubt that this factory construction brought about a revolution in the construction industry at that time. To some degree, the design concept of providing a good working environment for the working class can be regarded as modernism. (Referring with Fig.3)

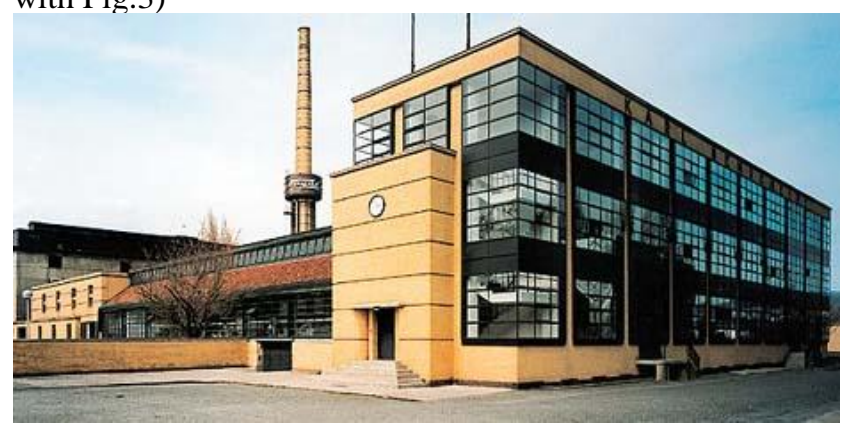

Figure 3. Example of an angle perspective figure caption

The use of glass curtain wall and corner windows innovated by Gropius is not only a new architectural language of modern architecture, providing new design method and new aesthetics for the architects, but also exposes the eternal truth that building's function and appearance are inseparable from modern materials and construction techniques, which has affected the modern architecture since then. (Referring with Fig.4, Fig.5 and Fig.6)

In June 25, 2011, the 35th World Heritage Conference was held in Paris, France. The Fagus Factory located in Alfeld, Saxony. Germany was added to the U.N. Educational, Scientific and Cultural Organization's World Heritage List. From then on, it began to enjoy the special protection of the world cultural heritage together with the buildings such as Palace of Versailles in Paris and Cologne Cathedral. It was the biggest certainty for the Fagus Factory.

The practices of the Fagus Factory, from where we derive a new thought and method, are widely used in the modern public buildings and houses of different sizes. What made the Fagus Factory truly successful are Gropius' respecting for science and technology progress in modern 
architecture and his design method used in appropriate manner to show architectural arts.

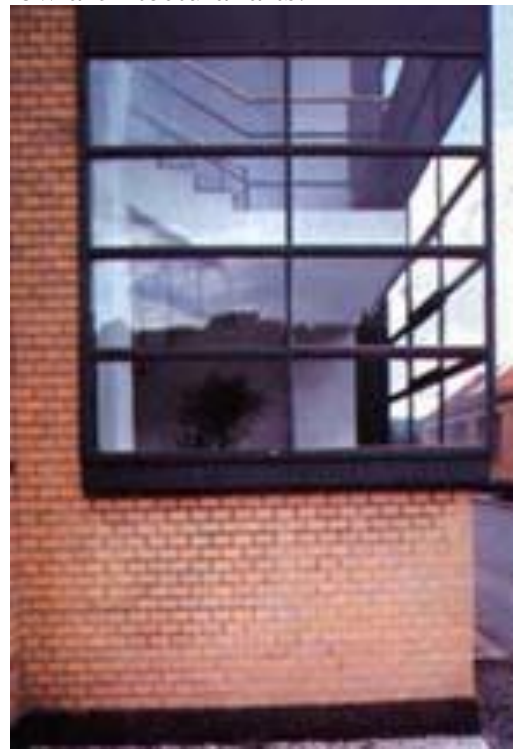

Figure 4. Example of a comer window (1) figure caption

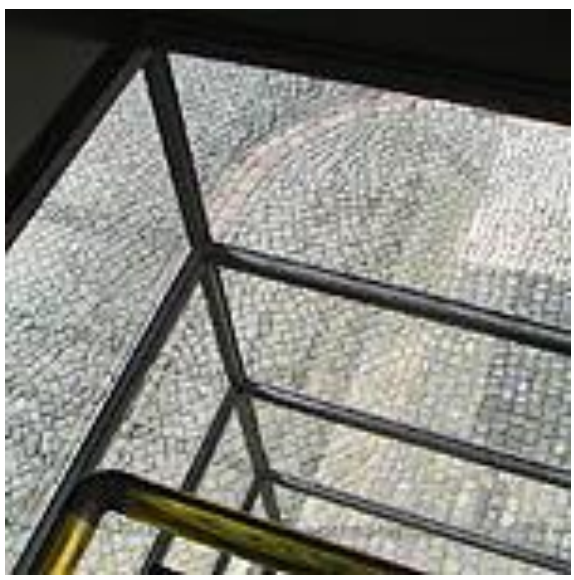

Figure 5. Example of a comer window (2) figure caption

In a few decades, glass became the major design material and symbolic language because of the Fagus Factory. And also in that period, glass was used by the pioneers of modern architects to the extreme. The sense of permeability became a common characteristic of the modern architecture.

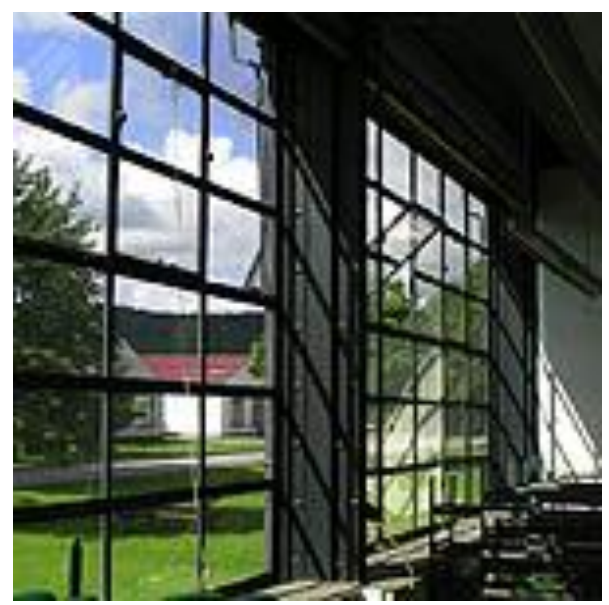

Figure 6. Example of a glass curtain figure caption

\section{CONCLUSION}

The Bauhaus School founded by Gropius has a considerable contribution to modern architectural education. His architectural thought and participation in the modern architectural associations play a very important role in the spread and development of modern architectural theory. Judging from the design education system, many industrial and architectural designs in the world are influenced by Gropius.

That was emphasis on practicability, the technical performance and aesthetic properties of new materials, simple shape and versatile composition. [1] So the Bauhaus School became one of the most radical centers for art and architecture in Europe, which promoted the building reform movement. [2] With glass brick walls dividing the space, the light can also seep in and the South side of the cornice perfectly designed by Gropius can hide the summer sun and emit heat, which made the house can withstand the heat in summer and resist the lowest record temperature $-21^{\circ} \mathrm{C}$ in winter. [3] The sense of permeability became a common characteristic of the modern architecture. [2]

\section{REFERENCES}

[1] Walter Adolph Georg Gropius, http://baike.baidu.com. 2015-01.

[2] Xue Ju, Zhou Chuanxin. Frozen Art. Beijing. Beijing Science and Technology Press. 2013-12. P6-14.

[3] Walter Adolph Georg Gropius: http://www.baike.com/wiki. 2015-01. 